\title{
Local Public Services Delivery Mechanisms: A Literature Review
}

\author{
Veronika Petkovšek, Nevenka Hrovatin \& Primož Pevcin
}

\begin{abstract}
The paper presents a systematic literature review on local public services delivery mechanisms, in-house provisions, privatization and inter-municipal cooperation, for the period 2007 to 2018 , with the aim of reviewing the development of the area under study, identifying which delivery mechanism dominates in a given period, and determining which economic research focus dominates in the area under study. Possible effects on economies of scale, cost reductions, efficiency, and other economic, political, institutional, and social factors in the provision of local public services are examined using a content analytical breakdown. The results show that most of the studies are country studies and, especially in recent years, empirical studies. The choice of local public services delivery mechanisms is mainly influenced by the size of local government, the efficiency of service provision, the available resources and the institutional framework. Politics and market competition also play a role in the decision-making process. Following the recent financial and economic crisis, inter-municipal cooperation is increasingly being researched as an efficient form of service provision.
\end{abstract}

Keywords: - local public services delivery mechanism • in-house provision $\bullet$ privatization $\cdot$ inter-municipal cooperation $\bullet$ literature review

CORRESPONDENCE AdDRESS: Veronika Petkovšek, M.Sc., University of Ljubljana, Faculty of Public Administration, Gosarjeva 5,1000 Ljubljana, Slovenia, email: veronika.petkovsek@fu.uni-lj.si. Nevenka Hrovatin, Ph.D., Professor, University of Ljubljana, School of Economics and Business, Kardeljeva ploščad 17, 1000 Ljubljana, Slovenia, email: nevenka.hrovatin@ef.uni-lj.si. Primož Pevcin, Ph.D., Associate Professor, University of Ljubljana, Faculty of Public Administration, Gosarjeva 5,1000 Ljubljana, Slovenia, email: primoz.pevcin@fu.uni-lj.si.

https://doi.org/10.4335/19.1.39-64(2021)

ISSN 1581-5374 Print/1855-363X Online (C) 2021 Lex localis

Available online at http://journal.lex-localis.press. 
The paper presents a literature review focusing on local public services delivery mechanisms. The potential impact on economies of scale, cost reductions, efficiency and other economic, political and institutional factors in the provision of local public services is examined. The aim of the paper is to review the development of the area under study - the three main service delivery mechanisms (i.e. in-house provision, privatization and inter-municipal cooperation) - to find out which delivery mechanism dominates in a given period of time and to verify which economic research focus prevails in the area under study. This will enable the existing reviews in the area under study to be updated and upgraded. Some authors (see e.g. Bel and Fageda, 2009; Bel and Warner, 2015) have already produced an overview of empirical studies on the privatization of local public services as well as an overview focusing on inter-municipal cooperation. The focus of this work is differentiated because it covers both empirical and nonempirical research (scientific papers), refers to all three delivery mechanisms and does not omit the country or cross-country focus of the literature. In this context, the research aims to both update the overview of the investigation of this field and at the same time try to be holistic by using both manifest and latent content analytical approaches. The research questions are: (1) How has the studied field developed over time and what are the general characteristics of the literature in the studied field? (2) What is the main research topic of the studies in the literature sample selected for our study? (3) What are the main findings of studies in the literature sample selected for our study? The first section of this paper is an introduction to the literature review of local public services delivery mechanisms with the research questions presented. The second section presents the methodology and data for the literature review on one hand, and the general characteristic of the literature review sample on the other. The third section deals with a content analysis breakdown, in which the research focus and the most important results of the analysed studies are examined. The last section of the paper contains conclusions on the content analysis breakdown.

\section{$2 \quad$ Methodology and data}

\subsection{Methodology}

The paper analyses empirical and non-empirical English language academic journal articles on the mechanisms of local public service delivery, selected on the basis of five keywords that will be discussed later in this section. Only scientific journal papers are reviewed, as this type of paper is the most rigorous way of communication between researchers. The scientific papers also included in this literature review are limited to the period from 2007 to 2018, when the number of papers on the subject under review increased significantly. The period from 2001 to 2006 was not so rich in scientific papers on the mechanisms of providing local 
public services; the databases researched contain only 1-3 papers per year for the keywords used. Since 2007 the number has increased to 6-8 scientific journal papers per keyword used per year. Especially in 2017 and 2018 the number has jumped to 10-20 papers per keyword per year. Such an increase in the recent years is probably due to the interest in alternative ways of local public services delivery. In particular, inter-municipal cooperation (hereinafter also referred to as 'IMC') has become very popular recently. The literature review is also limited to European and the US studies, as they present the majority of studies related to local public services delivery mechanisms.

A literature search was conducted using four of the most important scientific literature databases: Scopus, Web of Science (WoS), Business Source Premier, and Political Science Complete. The Scopus and WoS databases were used due to multidisciplinary bibliographic collections with a citation index, containing papers of the most influential scientific journals in the world. In addition, Business Source Premier and Political Science Complete were used because of our research topic on local public services delivery mechanisms, as our literature review is only limited to social science papers. The Business Source Premier database is intended for searching professional and academic literature in the field of economics, and the Political Science Complete database is intended for searching literature in the field of political science.

Many of the papers found are available in more than one database. Searching in more than one database is conditioned by the fact that this literature review attempts to give a holistic view of the research topic. The search in the selected databases was limited to the social sciences, more precisely to the economic and political sciences. Therefore, Scopus included three available research areas: 1) social sciences; 2) business, management, and accounting; and 3) economics, econometrics and finance. WoS included the following areas: 1) public administration; 2) business economics; and 3) other social science topics. Business Source Premier and Political Science Complete covered areas such as economic aspects, municipal services, liberalization, political science and policy sciences. Papers were searched with five keywords: 'local public services delivery mechanisms,' 'alternative local public service provision,' 'in-house local public services delivery,' 'private local public services delivery,' and 'inter-municipal cooperation.' The phrase 'local public service' is the central part of the keywords. 'Local public' was used because the focus of the literature review is on local government, and 'service,' because the review attempts to provide a broader insight into the delivery mechanisms of public services in general and goes beyond public utilities.

Therefore, the word 'utility' was not used as a part of the keywords. All keywords used cover the central topic of this literature review, the three local public services delivery mechanisms, namely in-house delivery, private service delivery, and 
inter-municipal cooperation as an alternative. The phrase 'delivery mechanisms' was also successfully used with the alternative phrase 'provision' in one of the keywords. When relevant papers with keywords and other explained selection criteria (time period, territory, research area) were identified, the titles of the total number of papers found were checked to exclude duplicate papers. The next step was to check the content - abstracts of these papers were read to determine the direct relevance of the content to our main topic. After that, open access to the full text of the remaining relevant papers was checked, followed by the second content check - reading the full text of the remaining papers. Some further papers were excluded because of their content irrelevance. In the end, a total of 50 relevant papers were included in our literature review and content analysis of the literature sample.

The selected literature sample is analysed by means of content analysis. Berelson (1952) defines 'content analysis' as a research technique to objectively, systematically and quantitatively describe the manifest content of communication. This paper provides the essential information and the underlying meaning of the methodology and the content about the existing literature in the area and period under study by using latent content analysis as a tool for conducting a literature review or as a tool for systematic and transparent analysis of a literature sample (Seuring and Gold, 2012). In the process of content analysis, we focus on the main research topic of each paper and its results. During this process we aim to find answers to several questions relevant to answering research questions related to the public services delivery mechanisms.

Therefore, based on the research questions presented in the Introduction, we have posed the following sub-questions that lead us to reach our objective: 1) When was the first study published, 2) How has the number of studies changed over time, 3) What types of studies have been carried out, 4) What methodology is used in the studies, 5) What research questions are asked in the studies, 6) Are there major differences in research questions between the studies, 7) What research topic is most strongly represented in the studies; 8) What are the decision-making factors influencing the local public services delivery, and 9) Are there major differences in the decision-making factors between studies/authors? The answers to these sub-questions were found by analysing the selected literature sample. As described in the previous paragraph, the next step was to select the communication content and sample for our literature review to answer the research questions. Then, by defining content categories, we determined the type of material to be included and completed the units of analysis. Finally, we performed the analysis of the collected data. 


\subsection{Data set}

The study of this field originated in the United States and the United Kingdom in the $21^{\text {st }}$ century, with authors Warner and Hebdon (2001) at the forefront with the paper Local Government Restructuring: Privatization and Its Alternatives. Empirical studies dominate over non-empirical studies. Despite the extensive literature in this field, it is a fact that a literature review is the background of almost every academic paper work, as it helps to narrow down the research topic. It seems that a comprehensive literature review on the local service delivery mechanism is still needed. It will contribute to a thorough synthesis of previous research on the selected research topic, which according to Seuring and Gold (2012) is one of the main steps of the research process.

As explained in Section 2.1., the literature sample was compiled using five keywords for search and content review. A total of 435 scientific papers were found in the area under investigation, 131 of which were duplicates. As far as the time period is concerned, the majority of the papers were published after 2006. In the period from 2001 to 2006 a total of 70 papers with five keywords were found. Only 1-3 papers per keyword were published per year. The publication boom in this area started in 2007, when 6-8 papers per keyword were published annually until 2016. A total of 279 of all papers found were published between 2007 and 2016. In the years 2017 - 2018 the number of published papers per keyword doubles annually. Altogether 86 papers were published in these two years, with 10-20 papers per keyword.

The largest number of papers found belong to the keywords 'local public services delivery mechanisms' (114 scientific journal papers found) and 'alternative local public service provision' (112 papers). Under the keyword 'private local public services delivery' 103 papers were identified, followed by 'inter-municipal cooperation' with 73 papers. The lowest number of papers is found under the keyword 'in-house local public services delivery' (33 papers). As already mentioned, many of these papers are duplicates found under more than one of the keywords. The total number of papers found without duplicates is therefore less than the sum of all papers per keywords. After the exclusion of 131 duplicates, 304 papers remained for the content analysis.

In the first content check, we read abstracts to identify the direct content relevance with our main topic; a total of 105 papers were relevant in terms of content. We then reviewed the full open access of these 105 papers, which reduced our sample to 62 papers. This was followed by the second substantive content examination, in which the entire text of these papers was read. Another 12 papers were excluded because of their irrelevance. To be more precise, reading the entire texts revealed that the main research focus of these papers was mostly related to environmental 
or social issues. We found 50 content-relevant papers with full paper open access that we could include in our literature sample.

Of these, 45 papers are available in Scopus, 40 in WoS, 12 in Political Science Complete and 10 papers were in Business Source Premier. As expected, the majority of the papers (38) are available in Scopus and WoS, which are known as two first-class databases for abstracts and citations from peer-reviewed literature. The other two databases, Business Source Premier and Political Science Complete, contain only 12 and 10 papers respectively, which was expected due to their specific field of research. However, nine papers from Political Science Complete are also available in Scopus and WoS, and seven papers from Business Source Premier in Scopus and WoS.

\section{General characteristics of the literature review sample}

First, we carried out the substantive content examination on the basis of the three types of local public services delivery mechanisms and their mix. As Table 1 shows, only one study focuses on in-house provision, 21 studies focus on private provision, 14 studies on inter-municipal cooperation, three studies on the mix of in-house and private provision and 12 studies on the mix of private provision and inter-municipal cooperation. No study investigates the mix of all three mechanisms.

The papers in Table 1 are also divided into country and cross-country studies for Europe and the USA. Of 50 papers, 39 are country studies, 24 of which are European and 15 are US studies. Of 11 cross-country studies, five are European and six are mixed European and US studies. In our literature sample there were no relevant cross-country (cross-states) US studies. In total, the literature sample includes 13 US studies, five Spanish studies, four studies covering the USA and Europe, four studies from the Netherlands, three Italian and Portuguese studies, two Swedish studies and two studies covering more European countries. In addition, there is one country study for each of the following countries: Germany, Poland, Denmark, Czech Republic and the Netherlands; and one cross-country study for each of the following countries: Czech Republic and Slovakia, the Netherlands and Spain, the United Kingdom and the USA, and the USA and Spain. These countries are study units and are not related to the country affiliations of the authors.

As Table 1 shows, the majority of the sample studies (36) were published in the period $2011-2018$ and refer to private provision or inter-municipal cooperation. Only 14 sample studies were published in the period 2007 - 2010, most of which relate to private service provision. With regard to the publication years, it can be seen that inter-municipal cooperation is a rather new topic. This type of delivery mechanism has gained in popularity in recent years and represents an alternative 
to private provision of services. In terms of content, therefore, the literature sample mainly includes the private provision of local public services (20 studies) and inter-municipal cooperation as an alternative to private provision (14 studies). The sample also includes 15 studies covering a mix of private provision and intermunicipal cooperation. Only one study in the sample focuses on in-house provision, and only three studies cover a mix of in-house and private provision of local public services. Most of the studies in the sample (39) cover country aspects, of which 24 studies are European country studies and 15 studies cover US states. The European country studies tend to focus mostly on either private service provision or on inter-municipal cooperation, while the US state studies focus more on the mix of local public services delivery mechanisms, as well as exclusively on private provision of services. However, there are no US state studies in our sample that focus exclusively on inter-municipal cooperation. Cross-country studies include only five studies in our sample that compare European countries, and only six studies compare European and US states. There are no papers in the sample with a cross-border dimension that only compare the US states. On the basis of the literature sample, we can conclude that there is a lack of studies that deal exclusively with the in-house provision of local public services, and also of studies that combine a mix of an in-house provision with the other two delivery mechanisms.

Table 2 gives an overview of the methodology used in the papers. The majority of the studies are empirical (43); 19 studies are quantitative, 17 qualitative and 14 include both quantitative and qualitative analyses. The majority of the sample studies use regression analysis (32), with probit and logit models being used most frequently. In addition, explanatory/descriptive/comparative analyses are used in seven studies, case study analyses in three studies and literature review analyses in two studies. Some also use other statistical methods. About half of the papers are based on secondary data, twenty-five percent on primary data, and twenty-five percent on a combination of both. The time frame of the data set varies from sample study to sample study, but about half of the empirical studies use longitudinal data and the other half use cross-sectional data.

Among the authors, Bel and Warner stand out with the highest number of papers in our sample, followed by Fageda, Hefetz, Gradus and Mur. Bel is the author of 11 papers (published between 2007 and 2018) dealing with private provision (three papers), inter-municipal cooperation (four papers) and a mix of private provision and IMC (four papers). Warner is the author of 10 papers (published between 2007 and 2016) dealing with private provision (three papers), intermunicipal cooperation (two papers) and a mix of private provision and IMC (five papers). Fageda also represents private provision (two papers), IMC (two papers) and a mix of private provision and IMC (one paper), with a total of five papers (published between 2008 and 2013). Gradus and Hefetz each appear in five sample papers, both representing private provision and a mix of private provision 
and IMC. Gradus, however, also represents a mix of in-house and private provision. In-house provision and private provision are also represented by Tavares. The Mur's papers in our sample mainly focus on IMC and a mix of private provision and IMC. Soukopová focuses on private provision and IMC, Allers on IMC, Dijkgraaf and Kim on a mix of private provision and IMC. The other authors appear in only one of the papers in our literature sample.

\section{Content analysis breakdown: research focus and findings of literature sample studies}

Based on the review of the sample studies, we can form six groups of factors influencing the decision on local public services delivery mechanisms. These are costs, economies of scale, efficiency, economic-political factors, economicinstitutional-social factors and other economic factors (e.g. fiscal conditions, poverty issues, quality, corporatization, competitive/non-competitive service markets, local stress, etc.). Each group covers studies from three perspectives, focusing on privatization, inter-municipal cooperation and both privatization and inter-municipal cooperation. Each group of decision-making factors shows which is the main research topic and the main findings of the studies in relation to each of the three delivery mechanisms. The content analysis breakdown is presented in Tables 3 - 8 .

The first group, costs as a decision-making factor, which is shown in Table 3, focuses primarily on cost reduction in the context of an individual delivery mechanism. In terms of the number of studies, it is also the most representative group of decision-making factors. The studies that analyse the relationship between costs and the privatization of local public services (Bel and Fageda, 2008; Hultquist et al., 2017; Nemec et al., 2015; Zafra-Gómez et al., 2013) focus on the impact of transaction costs on the choice of delivery modes, taking into account the contribution to cost reduction. The authors found that privatization is less common in local public services with higher transaction costs and in small local governments. Similarly, the studies analysing inter-municipal cooperation and cost behaviour (Bel and Warner, 2015; Bel et al., 2012; Soukopová and Vaceková, 2018) focus on cost reduction and the size of local governments. The main findings of the authors show that cost savings are more common in smaller local governments and are influenced by institutional arrangements of inter-municipal cooperation. The studies covering both delivery mechanisms - privatization and inter-municipal cooperation (Bel and Mur, 2009; Bel et al., 2010; Bel et al., 2013; Hefetz and Warner, 2011; Mohr et al., 2010; Dijkgraaf and Gradus, 2013) have a similar focus. The authors attempt to find out whether and under what conditions privatization or inter-municipal cooperation brings greater cost advantages of local public services delivery. The studies indicate that, from a cost reduction perspective, inter-municipal cooperation is preferable for smaller local governments and privatization for larger local governments. This may be 
explained by the lack of competition in small local governments, so that private provision would lead to higher transaction costs.

Similar to costs as one of the most important factors in choosing the most appropriate delivery mechanism, economies of scale (Table 4) are very closely linked to transaction costs. Therefore, many sample studies focusing directly on costs also analyse the relation between achieving economies of scale as a result of cost reduction and the chosen delivery mechanism. Levin and Tadelis (2010) studied the advantages of the size of local governments in achieving economies of scale in the case of privatization, while Warner (2011) examined this in the case of inter-municipal cooperation. Levin and Tadelis (2010) found that small local governments would not opt for privatization because it does not bring economies of scale advantages. Warner (2011) points out that inter-municipal cooperation is positively linked to the achievement of economies of scale, especially in small local governments where competition is limited.

The efficiency of local public service provision, as shown in Table 5, is another important economic factor influencing the local government's decision on public services delivery mode. Garrone and Marzano (2015) and Warner (2008) focus mainly on privatization and the associated efficiency gains in private service provision. They found that privatization is more likely in cases where scale and managerial efficiency have already been improved. Conversely, authors such as Allers and de Greef (2018); Allers and van Ommeren (2016); Blaesche and Haug (2018) and Grešová and Fuka (2018) try to find evidence of efficiency gains of service delivery in inter-municipal cooperation. The authors point out that cooperating local governments achieve lower technical efficiency than selfproviding governments. There are potential cost savings and positive scale effects in smaller local governments, but there is no clear evidence of efficiency gains in service delivery with IMC. The studies comparing the impact of private service provision and inter-municipal cooperation on efficiency (Hefetz et al., 2012; Monteduro, 2014; Czaplak, 2016) try to identify the relationship between these two delivery mechanisms and efficiency gains. The authors conclude that publicprivate service provision has a better economic performance than pure public provision. However, the key to improving efficiency is the supervision of service delivery, not the delivery mode itself.

Table 6 shows that studies related to economic-political factors focus mainly on the privatization of local public services (Warner and Hefetz, 2012; Sundell and Lapuente, 2012; Bel and Fageda, 2009; Carrozza, 2010; Rodrigues et al., 2012), especially on how the political environment influences a local government's decision on the private service provision. The authors' main findings show that the political environment and political dynamics have a large impact on local government decisions on the delivery mechanism, especially for small local governments. However, authors Tavares and Camöes (2007) also touch on the 
content of in-house service delivery. They look for elements that influence the decision on private provision or rather the in-house provision of certain local public services. They came to similar conclusions that a political and socioeconomic context has an important influence on the decision on the delivery mode. There were no studies in the reviewed literature sample that dealt only with political decision-making factors for IMC.

Economic-institutional-social factors (Table 7) observed in the analysed studies refer to the stability of service provision as an institutional factor and ideology and neighbourhood effect as social factors, all of which are related to the economic performance and efficiency of local public service delivery. In the case of privatization, Wassenaar et al. (2013), González-Gómez et al. (2011), Petersen et al. (2015) and Bel et al. (2007) try to find out which institutional and socioeconomic factors lead to private service provision. The authors found that more complex operating environments, financial difficulties and a larger size of local government would lead to privatization or outsourcing of local public services. In contrast, ideology has less impact on the decision to privatize. Studies focusing on inter-municipal cooperation (Hulst et al., 2009; Klimovsky et al., 2014; Rayle and Zegras, 2013; Bel and Warner, 2016) analyse the impact of these factors on various inter-municipal cooperation arrangements. The authors point out that the combination of all factors - the institutional context, local government preferences, interpersonal relationships and organizational characteristics influences the decision on the specific pattern of cooperation.

In addition, there are other economic decision-making factors (e.g. fiscal conditions, poverty issues, quality, corporatization, competitive/non-competitive service markets, local stress, etc.) that are analysed in the sample studies (Table 8). Krueger et al., (2011); Lamothe et al., (2008); Schoute et al., 2018; Marvel and Marvel (2007); and Bergman et al., (2016) examine other economic factors that could influence the privatization of local public services. The authors' main findings suggest that, among other things, limited available resources, asset specificity, inertia effects, the competitiveness of the contract environment, monitoring of service delivery, and emphasis on outcome performance also influence the decision on private service delivery. Citroni et al., (2013) and Wollmann (2011) try to find out whether inter-municipal cooperation is enhanced through corporatization, and whether IMC is also influenced by other economic factors. They found that IMC is enhanced by corporatisation, which helps local governments to choose their style of cooperation. Studies dealing with privatization and IMC as an alternative (Warner and Bel, 2008; Girth et al., 2012; Kim and Warner, 2016; Bel and Gradus, 2018; Kim, 2018) attempt to identify which factors drive local governments to choose IMC as an alternative to privatization in local public services delivery, and at the same time what are the effects of privatization or IMC as an alternative to certain local public service provision. The authors came to the general conclusions that both privatization and 
IMC are influenced by fiscal stress and the community needs, both mechanisms are subject to obstacles, but monopoly services are more likely to be provided through intergovernmental contracting, and more competitive markets tend to use more for-profit contacting.

In the context of other economic decision-making factors, such as fiscal conditions, poverty issues and local stress, the last global financial and economic crisis has undoubtedly influenced the choice of the public service delivery mechanism in search of its optimization. The focus of analysed studies after 2009 has become more oriented to inter-municipal cooperation as a mechanism delivery option which in some cases brings higher cost savings and greater efficiency than pre-crisis privatization. In 2007 - 2009, studies analysed privatization (of a total of 9 sample studies, 5 studies cover privatization, 3 studies deal with privatization versus IMC and only 1 study deals only with IMC). The issues addressed in these studies are of a more general nature, such as the reduction of transaction costs for the provision of service delivery, the satisfaction of citizens' interests, the influence of the political environment, the competitiveness of the contracting environment and the influence of the size of the local community. After 2009, the trend shifted from privatization to IMC. In this context, 13 sample studies explicitly focus on IMC and 12 studies analyse IMC versus privatization. Although 15 sample studies still focus mainly on privatization, it is obvious that IMC is becoming increasingly attractive as an efficient delivery option. Furthermore, the general nature of the analyses carried out before 2009 has changed to a more specific type of analysis, emphasizing fiscal conditions, socioeconomic factors, ideological factors and different market approaches, often related to the size of the local community, in order to find the most efficient delivery option.

To conclude the content analysis breakdown, the main findings of the studies analysed show that the size of the local authority is relevant for the decision on the delivery mechanism for local public services. Most of these studies confirm the fact that privatization is the more common and realistic option for large local governments when it comes to cost reduction, economies of scale and efficiency, while it is not so preferable option for small local governments, for which the IMC is a better solution. Due to the greater fiscal constraints faced by small local governments, more emphasis has been placed over the last decade on analysing IMC as a better and more efficient alternative to privatization. In this context it is expected that local communities, especially smaller ones, will face even greater fiscal constraints and socio-economic stress due to the current COVID-19 crisis. Therefore, the forthcoming studies will most likely continue to focus on the IMC delivery mechanism, which enables local communities to deliver local public services in the most cost-efficient way while ensuring the highest satisfaction of local citizens. This is becoming somehow evident, as IMC is again becoming a more prominent topic in the literature, as suggested by recent references from 
2019 and 2020. Let us briefly outline the trends in these two years that are not covered in our detailed literature review.

As far as the number of papers is concerned, it remains the same, about 10-20 papers per year per keyword 'local public services delivery mechanisms' and 'alternative local public service provision'. However, a noticeable difference can be seen in the keywords illustrating a single delivery mechanism: the number of papers with the keyword 'in-house local public services delivery' has decreased to only 2-5 papers per year, while the number of papers with the keyword 'private local public services delivery' has risen to 20-40 papers per year and with the keyword 'inter-municipal cooperation' to 15-30 papers per year. Using the same criteria for the literature review in these last two years as in our study period, we identified 30 relevant papers. One half of the 30 relevant studies originated in the USA and the other half are European studies. 1/3 of all relevant studies are crosscountry and the other $2 / 3$ are country studies. All relevant studies are empirical, except one, which presents a literature review. IMC remains a very popular research topic with 14 of 30 studies referring to IMC. Most of these are European studies (around 64\%), of which almost $78 \%$ are country studies. In contrast, most studies that refer to private provision refer to the USA. The research trend is also towards re-municipalisation and reverse contracting, as well as towards collaboration with governmental and non-governmental non-profit organizations. The country coverage of these topics is relatively evenly distributed between the European and US studies.

Prominent authors such as Bel, Warner, Camöes, Rodrigues and Nemec continue to publish with many new authors who join them with their research results, mostly in relation to privatization and IMC as an alternative. Let us briefly present the most important findings of the authors mentioned above. Warner, Aldag and Kim (2020) and Aldag, Warner and Bel (2020) address IMC as one of the most common forms of local public service delivery and also as the most relevant alternative to local public service delivery choice, as it better responds to fiscal burdens and the needs of local citizens and leads to cost reductions; however, the authors also stress the limited role of cost reductions and economies of scale. Furthermore, Albalate and Bel (2020) and Warner and Aldag (2019) touch remunicipalisation, as one of the new trends in local government in the USA and Europe. Their findings show that re-municipalisation occurs more frequently in local governments with private contractors and is not primarily driven by political interests, but by the preferences of bureaucrats. Reverse contracting has also been a popular research topic in recent years. Camöes and Rodrigues (2020) found that economic and financial rather than political aspects are the key drivers of reverse contracting. Last but not least, Nemec (2019) is also investigating cooperation with the third sector to achieve more efficient service delivery. His results highlight that the limited financial resources on both sides are the biggest barrier for efficient cooperation. In summary, economic conditions and the needs of the 
local population push local governments to look for the most efficient cost-saving way of local public services delivery, also with a focus on the service quality. This is why, in the last two years, other concepts such as re-municipalisation, reverse contracting, public-private partnership and third sector participation have come to the fore alongside the IMC as a very popular alternative today.

\section{5}

\section{Conclusion}

The paper provides a literature review on local public services delivery mechanisms, in the period 2007 - 2018, focusing on possible effects on economies of scale, cost reductions, efficiency and other economic, political and institutional factors in the provision of local public services. With this literature review, the paper gives answers to three research questions posed in the Introduction.

The answer to the first research question on the development and general characteristics of the literature in the studied field and period under study provides the following conclusions. This topic represents a rather new field of research, which has become very popular in the last years 2017 - 2018 and has seen a strong increase in the number of published journal papers. Most of the papers examine private local service provision or the IMC in local service provision or a combination of both. There is a great lack of scientific journal papers dealing with the in-house provision of local public services, which makes it difficult to compare all three delivery mechanisms. Most of the papers are empirical studies and are mostly done on a country level; therefore, the results and findings are also bound to a specific national context and a specific local government framework and may therefore vary from country to country. The majority of sample studies use regression analysis, but there are also studies that use explanatory, descriptive and/or comparative analysis, case study analysis, a literature review and other statistical methods.

The answer to the second research question, which relates to the main research topic of the studies analysed, shows that the research topics are very similar among the sample studies. The studies focus mainly on cost reduction and achieving economies of scale in relation to the size of local government, on efficiency gains and on the impact of political, institutional, social and financial factors on the choice of delivery mechanism.

The answer to the third research question, which refers to the main findings of the studies analysed, generally shows that decisions on local public services delivery mechanisms are mainly influenced by the size of local government, the efficiency of service provision, the resources available and the institutional framework. Politics and competition in the market are also important decision-making factors. Most authors find that large local governments tend to prefer private service provision, while small local governments prefer IMC. This finding is directly 
related to the potential cost reductions resulting from economies of scale and efficiency.

The research trend towards more cost-efficient solutions for local public services delivery can be observed in the period after 2009 and has been further highlighted in recent papers published in 2019 and 2020. These papers focus mainly on IMC; several still deal with private service provision, but with more links to publicprivate partnership, reverse contracting, re-municipalisation and third sector cooperation. It is clear that the focus of the studies is changing due to the changing fiscal conditions of local governments and the changing needs of local citizens. The recent financial and economic crisis and most likely the current COVID-19 crisis has also had a significant impact on the scientific field of writing, which reflects the search for the most effective local public services delivery mechanisms.

The holistic approach used in this paper distinguishes this literature review from other existing literature reviews in the studied field, as it includes empirical and non-empirical studies that address all three local public services delivery mechanisms. This literature review explores the existing reviews in this research area by examining several dimensions that affect the choice of delivery mechanism by local governments. However, limitations related to the choice of the literature sample leave room for a more comprehensive literature review of local public services delivery mechanisms.

\section{References:}

Albalate, D. \& Bel, G. (2020) Politicians, bureaucrats and the public-private choice in public service delivery: anybody there pushing for remunicipalization?, Journal of Economic Policy Reform, https://doi.org/10.1080/17487870.2019.1685385.

Aldag, A., Warner, M. E. \& Bel, G. (2020) It depends on What You Share: The Elusive Cost Savings from Service Sharing, Journal of Public Administration Research and Theory, 30(2), pp. 275-289, https://doi.org/10.1093/jopart/muz023.

Allers, M. A. \& de Greef, J. A. (2018) Intermunicipal Cooperation, Public Spending and Service Levels, Local Government Studies, 44(1), pp. 127-150, https://doi.org/10.1080/03003930.2017.1380630.

Allers, M. A. \& van Ommeren, B. (2016) Intermunicipal Cooperation, Municipal Amalgamation and the Price of Credit, Local Government Studies, 42(5), pp. 717-738, https://doi.org/10.1080/03003930.2016.1171754.

Bel, G. \& Fageda, X. (2008) Reforming the Local Public Sector: Economics and Politics in Privatization of Water and Solid Waste, Journal of Economic Policy Reform, 11(1), pp. 45-65, https://doi.org/10.1080/17487870802134884.

Bel, G. \& Fageda, X. (2009) Factors Explaining Local Privatization: A Meta-Regression Analysis, Public Choice, 139(1-2), pp. 105-119, https://doi.org/10.1007/s11127-0089381-z. 


\section{LEX LOCALIS - JOURNAL OF LOCAL SELF-GOVERNMENT V. Petkovšek, N. Hrovatin \& P. Pevcin: Local Public Services Delivery Mechanisms: A Literature Review}

53

Bel, G. \& Gradus, R. (2018) Privatisation, Contracting-Out and Inter-Municipal Cooperation: New Developments in Local Public Service Delivery, Local Government Studies, 44(1), pp. 11-21, https://doi.org/10.1080/03003930.2017.1403904.

Bel, G., \& Mur, M. (2009) Inter-Municipal Cooperation, Privatization and Waste Management Costs: Evidence from Rural Municipalities, Waste Management, 29(10), pp. 2772-2778, https://doi.org/10.1016/j.wasman.2009.06.002.

Bel, G. \& Warner, M. E. (2015) Inter-Municipal Cooperation and Costs: Expectations and Evidence, Public Administration, 93(1), pp. 52-67, https://doi.org/10.1111/padm.12104.

Bel, G. \& Warner, M. E. (2016) Factors Explaining Inter-Municipal Cooperation in Service Delivery: A Meta-Regression Analysis, Journal of Economic Policy Reform, 19(2), pp. 91-115, https://doi.org/10.1080/17487870.2015.1100084.

Bel, G., Dijkgraaf, E., Fageda, X. \& Gradus, R. (2010) Similar Problems, Different Solutions: Comparing Refuse Collection in the Netherlands and Spain, Public Administration, 88(2), pp. 479-495, https://doi.org/10.1111/j.1467-9299.2009.01808.x.

Bel, G., Fageda, X. \& Mur, M. (2012) Does Cooperation Reduce Service Delivery Costs? Evidence from Residential Solid Waste Services, Journal of Public Administration Research and Theory, 24(1), pp. 85-107.

Bel, G., Fageda, X. \& Mur, M. (2013) Why Do Municipalities Cooperate to Provide Local Public Services? An Empirical Analysis, Local Government Studies, 39(3), pp. 435-454, https://doi.org/10.1080/03003930.2013.781024.

Bel, G., Hebdon, R. \& Warner, M. E. (2007) Local Government Reform: Privatisation and Its Alternatives, Local Government Studies, 33(4), pp. 507-515, https://doi.org/10.1080/03003930.2013.781024.

Berelson, B. (1952) Content Analysis in Communication Research (New York: The Free Press).

Bergman, M. A., Johansson, P., Lundberg, S. \& Spagnolo, G. (2016) Privatization and Quality: Evidence from Elderly Care in Sweden, Journal of Health Economics, 49, pp. 109-119, https://doi.org/10.1016/j.jhealeco.2016.06.010.

Blaeschke, F. \& Haug, P. (2018) Does Intermunicipal Cooperation Increase Efficiency? A Conditional Metafrontier Approach for the Hessian Wastewater Sector, Local Government Studies, 44(1), pp. 151-171, https://doi.org/10.1080/03003930.2017.1395741.

Camöes, P. J. \& Rodrigues, M. (2020) From enthusiasm to disenchantment: an analysis of the termination of Portuguese municipal enterprises, Public Money \& Management, Early Access, https://doi.org/10.1080/09540962.2020.1763605.

Carrozza, C. (2010) Privatising Local Public Services: Between Industrial Legacy and Political Ambition, Local Government Studies, 36(5), pp. 599-616, https://doi.org/10.1080/03003930.2010.506975.

Citroni, G., Lippi, A. \& Profeti, S. (2013) Remapping the State: Inter-municipal Cooperation through Corporatisation and Public-Private Governance Structures, Local Government Studies, 39(2), pp. 208-234, https://doi.org/10.1080/03003930.2012.707615.

Czaplak, J. (2016) Analysis of the Effectiveness of Public Services Provision by Local Governments in the Years 2007-2013, Oeconomia Copernicana, 7(2), pp. 223-243, https://doi.org/10.12775/OeC.2016.014.

Dijkgraaf, E. \& Gradus, R. (2013) Cost Advantage Cooperations Larger than Private Waste Collectors, Applied Economics Letters, 20, pp. 702-705, https://doi.org/10.1080/13504851.2012.732682. 
Garrone, P. \& Marzano, R. (2015) Why Do Local Governments Resist Contracting Out? Urban Affairs Review, 51(5), pp. 616-648, https://doi.org/10.1177/1078087414549548.

Girth, A. M., Hefetz, A., Johnston, J. M. \& Warner, M. E. (2012) Outsourcing Public Service Delivery: Management Responses in Noncompetitive Markets, Public Administration Review, 72(6), pp. 887-900, https://doi.org/10.1111/j.15406210.2012.02596.x.

González-Gómez, F., Picazo-Tadeo, A. J. \& Guardiola, J. (2011) Why Do Local Governments Privatize the Provision of Water Services? Empirical Evidence from Spain, Public Administration, 89(2), pp. 471-492, https://doi.org/10.1111/j.14679299.2010.01880.x.

Grešová, L. \& Fuka, J. (2018) Perception of Intermunicipal Cooperation via Managerial Approach: Centralized Decisions or Voluntary Principle - What is More Efficient? Lex Localis - Journal of Local Self-Government, 16(3), pp. 431-452, https://doi.org/10.4335/16.3.431-452(2018).

Hefetz, A. \& Warner, M. E. (2011) Contracting or Public Delivery? The Importance of Service, Market, and Management Characteristics, Journal of Public Administration Research and Theory, 22(2), pp. 289-317, https://doi.org/10.1093/jopart/mur006.

Hefetz, A., Warner, M. E. \& Vigoda-Gadot, E. (2012) Privatization and Inter-municipal Contracting: The US Local Government Experience 1992-2007, Environment and Planning C: Government and Policy, 30(4), pp. 675-692.

Hulst, R., van Montfort, A., Haveri, A., Airaksinen, J. \& Kelly, J. (2009) Institutional Shifts in Inter-municipal Service Delivery. An Analysis of Developments in Eight Western European Countries, Public Organization Review, 9, pp. 263-285, https://doi.org/10.1007/s11115-009-0085-8.

Hultquist, A., Harsell, D. M., Wood, R. S. \& Flynn, D. T. (2017) Assessing the Impacts of Transaction Costs and Rapid Growth on Local Government Service Provision and Delivery Arrangement Choices in North Dakota, Journal of Rural Studies, 53, pp. 1425, https://doi.org/10.1016/j.jrurstud.2017.05.003.

Kim, Y. (2018) Can Alternative Service Delivery Save Cities After the Great Recession? Barriers to Privatisation and Cooperation, Local Government Studies, 44(1), pp. 44-63, https://doi.org/10.1080/03003930.2017.1395740.

Kim, Y. \& Warner, M. E. (2016) Pragmatic Municipalism: Local Government Service Delivery After the Great Recession, Public Administration, 94(3), pp. 789-805, https://doi.org/10.1111/padm.12267.

Klimovský, D., Mejere, O., Mikolaityte, J., Pinterič, U. \& Saparniene, D. (2014) Intermunicipal Cooperation in Lithuania and Slovakia: Does Size Structure Matter? Lex Localis - Journal of Local Self-Government, 12(3), pp. 643-658, https://doi.org/10.4335/12.3.643-658(2014).

Krueger, S., Walker, R. W. \& Bernick, E. (2011) The Intergovernmental Context of Alternative Service Delivery Choices, The Journal of Federalism, 41(4), pp. 686-708, https://doi.org/10.1093/publius/pjr035.

Lamothe, S., Lamothe, M. \& Feiock, R. C. (2008) Examining Local Government Service Delivery Arrangements Over Time, Urban Affairs Review, 44(1), pp. 27-56, https:/doi.org/10.1177/1078087408315801.

Levin, J. \& Tadelis, S. (2010) Contracting for Government Services: Theory and Evidence from U.S. Cities, The Journal of Industrial Economics, 58(3), pp. 507-541, https:/doi.org/10.1111/j.1467-6451.2010.00430.x. 
Marvel, M. K. \& Marvel, H. P. (2007) Outsourcing Oversight: A Comparison of Monitoring for In-house and Contracted Services, Public Administration Review, 67(3), pp. 521-530, https://doi.org/10.1111/j.1540-6210.2007.00734.x.

Mohr, R., Deller, S. C. \& Halstead, J. M. (2010) Alternative Methods of Service Delivery in Small and Rural Municipalities, Public Administration Review, 70(6), pp. 894-905, https://doi.org/10.1111/j.1540-6210.2010.02221.x.

Monteduro, F. (2014) Public-Private Versus Public Ownership and Economic Performance: Evidence from Italian Local Utilities, Journal of Management and Governance, 18(1), pp. 29-49, https://doi.org/10.1007/s10997-012-9235-4.

Nemec, J., Soukopová, J. \& Mikušová Meričková, B. (2015) Economic Aspects of the Municipal Waste Management: The Czech Republic and Slovakia, Hrvatska $i$ komparativna javna uprava - Croatian and Comparative Public Administration, 15(3), pp. 645-666.

Nemec, J., Svidroňová, M.M. \& Kovács, E. (2019) Welfare Co-Production: Hungarian and Slovak Reality, Nispacee Journal of Public Administration and Policy, 12(2), pp. 195215, https://doi.org/10.2478/nispa-2019-0019.

Petersen, O. H., Houlberg, K. \& Christensen, L. R. (2015) Contracting Out Local Services: A Tale of Technical and Social Services, Public Administration Review, 75(4), pp. 560570, https:/doi.org/10.1111/puar.12367.

Rayle, L. \& Zegras, C. (2013) The Emergence of Inter-Municipal Collaboration: Evidence from Metropolitan Planning in Portugal, European Planning Studies, 21(6), pp. 867-889, https://doi.org/10.1080/09654313.2012.722932.

Rodrigues, M., Tavares, A. F. \& Araújo, J. F. (2012) Municipal Service Delivery: The Role of Transaction Costs in the Choice Between Alternative Governance Mechanisms, Local Government Studies, 38(5), pp. 615-638, https://doi.org/10.1080/03003930.2012.666211.

Schoute, M., Budding, T. \& Gradus, R. (2018) Municipalities' Choices of Service Delivery Modes: The Influence of Service, Political, Governance, and Financial Characteristics, International Public Management Journal, 21(4), pp. 502-532, https://doi.org/10.1080/10967494.2017.1297337.

Seuring, S. \& Gold, S. (2012) Conducting Content-analysis-based Literature Reviews in Supply Chain Management, Supply Chain Management: An International Journal, 17(5), pp. 544-555, https://doi.org/10.1108/13598541211258609.

Soukopová, J. \& Vaceková, G. (2018) Internal Factors of Intermunicipal Cooperation: What Matters Most and Why?, Local Government Studies, 44(1), pp. 105-126, https://doi.org/10.1080/03003930.2017.1395739.

Sundell, A. \& Lapuente, V. (2012) Adam Smith or Machiavelli? Political Incentives for Contracting Out Local Public Services, Public Choice, 153(3-4), pp. 469-485, https://doi.org/10.1007/s11127-011-9803-1.

Tavares, A. F. \& Camöes, P. J. (2007) Local Service Delivery Choices in Portugal: A Political Transaction Costs Framework, Local Government Studies, 33(4), pp. 535-553, https://doi.org/10.1080/03003930701417544.

Warner, M. E. (2008) Reversing Privatization, Rebalancing Government Reform: Markets, Deliberation and Planning, Policy and Society, 27(2), pp. 163-174, https://doi.org/10.1016/j.polsoc.2008.09.001.

Warner, M. E. (2011) Competition or Cooperation in Urban Service Delivery? Annals of Public and Cooperative Economics, 82(4), pp. 421-435. 
Warner, M.E. \& Aldag, A.M. (2019) Re-municipalization in the US: a pragmatic response to contracting, Journal of Economic Policy Reform, Early Access, https://doi.org/10.1080/17487870.2019.1646133.

Warner, M.E., Aldag, A.M. \& Kim, Y. (2020) Privatization and intermunicipal cooperation in US local government services: balancing fiscal stress, need and political interests, Public Management Review, Early Access, https://doi.org/10.1080/14719037.2020.1751255.

Warner, M. E. \& Bel, G. (2008) Competition or Monopoly? Comparing Privatization of Local Public Services in the US and Spain, Public Administration, 86(3), pp. 723-735, https.//doi.org/10.1111/j.1467-9299.2008.00700.x.

Warner, M. E. \& Hefetz, A. (2012) Insourcing and Outsourcing, Journal of the American Planning Association, 78(3), pp. 313-327.

Wassenaar, M., Groot, T. \& Gradus, R. (2013) Municipalities' Contracting Out Decisions: An Empirical Study on Motives, Local Government Studies, 39(3), pp. 414-434, https://soi.org/10.1080/03003930.2013.778830.

Wollmann, H. (2011) Provision of Public Services in European Countries: From Public/Municipal to Private and Reverse? Hrvatska i komparativna javna uprava Croatian and Comparative Public Administration, 11(4), pp. 889-910.

Zafra-Gómez, J. L., Prior, D., Plata Díaz, A. M. \& López-Hernández, A. M. (2013) Reducing Costs in Times of Crisis: Delivery Forms in Small and Medium-Sized Local Governments' Waste Management Services, Public Administration, 91(1), pp. 51-68, https://doi.org/10.1111/j.1467-9299.2011.02012.x.

\section{Appendix:}

Table 1: Literature sample review by type of delivery mechanism and by country coverage

\begin{tabular}{|c|c|c|c|c|c|}
\hline $\begin{array}{l}\text { Country } \\
\text { studies } \\
\end{array}$ & $\begin{array}{r}\text { Delivery } \\
\text { mechanism } \\
\text { studies }\end{array}$ & $\begin{array}{l}\text { In-house } \\
\text { provision }\end{array}$ & $\begin{array}{l}\text { Private } \\
\text { provision }\end{array}$ & $\begin{array}{l}\text { Inter- } \\
\text { municipal } \\
\text { cooperation }\end{array}$ & $\begin{array}{l}\text { Mixed } \\
\text { delivery } \\
\text { mechanisms }\end{array}$ \\
\hline $\begin{array}{l}\text { Country } \\
\text { studies }\end{array}$ & Europe & $\begin{array}{l}\text { Tavares, } \\
\text { A.F. and } \\
\text { Camöes, } \\
\text { P.J. } \\
(2007)\end{array}$ & $\begin{array}{l}\text { Bel, G. and } \\
\text { Fageda, X. } \\
\text { (2008) } \\
\text { Carrozza, C. } \\
(2010) \\
\text { González- } \\
\text { Gómez, F. et } \\
\text { al., (2011) } \\
\text { Rodrigues, M. } \\
\text { et al., (2012) } \\
\text { Sundell, A. and } \\
\text { Lapuente, V. } \\
\text { (2012) }\end{array}$ & $\begin{array}{l}\text { Bel, G. et al., } \\
\text { (2012) } \\
\text { Citroni, G. et } \\
\text { al., (2013) } \\
\text { Bel, G. et al., } \\
\text { (2013) } \\
\text { Rayle, L. and } \\
\text { Zegras, C. } \\
\text { (2013) } \\
\text { Allers, M.A. } \\
\text { and van } \\
\text { Ommeren, B. } \\
\text { (2016) }\end{array}$ & $\begin{array}{l}\text { Bel, G. and } \\
\text { Mur, M. } \\
\text { (2009) } \\
\text { Dijkgraaf, E. } \\
\text { and Gradus, } \\
\text { R. (2013) } \\
\text { Monteduro, } \\
\text { F. (2014) } \\
\text { Czaplak, J. } \\
\text { (2016) }\end{array}$ \\
\hline
\end{tabular}


LEX LOCALIS - JouRnAl of LOCAL SELF-GOVERnMENT

V. Petkovšek, N. Hrovatin \& P. Pevcin: Local Public Services Delivery

Mechanisms: A Literature Review

\begin{tabular}{|c|c|c|c|c|c|}
\hline \multirow[t]{3}{*}{$\begin{array}{l}\text { Country } \\
\text { studies } \\
\end{array}$} & $\begin{array}{r}\text { Delivery } \\
\text { mechanism } \\
\text { studies }\end{array}$ & $\begin{array}{l}\text { In-house } \\
\text { provision }\end{array}$ & $\begin{array}{l}\text { Private } \\
\text { provision }\end{array}$ & $\begin{array}{l}\text { Inter- } \\
\text { municipal } \\
\text { cooperation }\end{array}$ & $\begin{array}{l}\text { Mixed } \\
\text { delivery } \\
\text { mechanisms }\end{array}$ \\
\hline & & & $\begin{array}{l}\text { Zafra- Gómez } \\
\text { et al., (2013) } \\
\text { Wassenaar, M. } \\
\text { et al. (2013) } \\
\text { Petersen et al. } \\
\text { (2015) } \\
\text { Garrone, P. and } \\
\text { Marzano, R. } \\
\text { (2015) } \\
\text { Bergman, P.A. } \\
\text { et al., (2016) }\end{array}$ & $\begin{array}{l}\text { Allers, M.A. } \\
\text { and de Greef } \\
\text { J.A. (2018) } \\
\text { Blaesche, F. } \\
\text { and Haug, P. } \\
\text { (2018) } \\
\text { Soukopová, J. } \\
\text { and } \\
\text { Vaceková, G. } \\
\text { (2018) } \\
\text { Grešová, L. } \\
\text { and Fuka, J. } \\
\text { (2018) }\end{array}$ & \\
\hline & The USA & & $\begin{array}{l}\text { Lamothe et al. } \\
(2008) \\
\text { Bel, G. and } \\
\text { Fageda, X. } \\
\text { (2009) } \\
\text { Levin, J. and } \\
\text { Tadelis, S. } \\
\text { (2010) } \\
\text { Krueger, S. et } \\
\text { al., (2011) } \\
\text { Warner, M.E. } \\
\text { and Hefetz, A. } \\
\text { (2012) } \\
\text { Girth, A.M. et } \\
\text { al. (2012) } \\
\text { Hultquist, A. } \\
\text { et al., (2017) }\end{array}$ & & $\begin{array}{l}\text { Marvel, M.K. } \\
\text { and Marvel, } \\
\text { H.P. (2007) } \\
\text { Mohr, R. et } \\
\text { al., (2010) } \\
\text { Warner, M.E. } \\
\text { (2011) } \\
\text { Hefetz, A. } \\
\text { and Warner, } \\
\text { M.E. (2011) } \\
\text { Hefetz, A. et } \\
\text { al., (2012) } \\
\text { Kim, Y. and } \\
\text { Warner, M.E. } \\
\text { (2016) } \\
\text { Kim, Y. } \\
\text { (2018) } \\
\text { Schoute, M. } \\
\text { et al. (2018) }\end{array}$ \\
\hline $\begin{array}{l}\text { Cross- } \\
\text { country } \\
\text { studies }\end{array}$ & Europe & & $\begin{array}{l}\text { Nemec, J. et } \\
\text { al., (2015) }\end{array}$ & $\begin{array}{l}\text { Hulst, R. et } \\
\text { al. (2009) } \\
\text { Wollmann, H. } \\
\text { (2011) }\end{array}$ & $\begin{array}{l}\text { Bel, G. et al., } \\
(2010)\end{array}$ \\
\hline
\end{tabular}


V. Petkovšek, N. Hrovatin \& P. Pevcin: Local Public Services Delivery

Mechanisms: A Literature Review

\begin{tabular}{|c|c|c|c|c|c|}
\hline \multirow[t]{3}{*}{$\begin{array}{l}\text { Country } \\
\text { studies } \\
\end{array}$} & $\begin{array}{r}\text { Delivery } \\
\text { mechanism } \\
\text { studies }\end{array}$ & $\begin{array}{l}\text { In-house } \\
\text { provision }\end{array}$ & $\begin{array}{l}\text { Private } \\
\text { provision }\end{array}$ & $\begin{array}{l}\text { Inter- } \\
\text { municipal } \\
\text { cooperation }\end{array}$ & $\begin{array}{l}\text { Mixed } \\
\text { delivery } \\
\text { mechanisms }\end{array}$ \\
\hline & & & & $\begin{array}{l}\text { Klimovský, } \\
\text { D. et al. } \\
\text { (2014). }\end{array}$ & \\
\hline & $\begin{array}{l}\text { Europe } \\
\text { and } \\
\text { the USA }\end{array}$ & & $\begin{array}{l}\text { Bel, G. et al., } \\
\text { (2007) } \\
\text { Warner, M.E. } \\
(2008)\end{array}$ & $\begin{array}{l}\text { Bel, G. and } \\
\text { Warner, M.E. } \\
\text { (2015) } \\
\text { Bel, G. and } \\
\text { Warner, M.E. } \\
\text { (2016) }\end{array}$ & $\begin{array}{l}\text { Warner, M.E. } \\
\text { and Bel, G. } \\
\text { (2008) } \\
\text { Bel, G. and } \\
\text { Gradus, R. } \\
\text { (2018) }\end{array}$ \\
\hline
\end{tabular}

Table 2: Review of methodology in literature sample

\begin{tabular}{|c|c|c|c|c|}
\hline Study & $\begin{array}{c}\text { Empirical/ } \\
\text { non-empirical } \\
\text { study }\end{array}$ & $\begin{array}{c}\text { Country/ } \\
\text { cross-country } \\
\text { study } \\
\end{array}$ & $\begin{array}{c}\text { Qualitative/ } \\
\text { quantitative } \\
\text { study }\end{array}$ & $\begin{array}{c}\text { Research } \\
\text { method/model, data, } \\
\text { time frame }\end{array}$ \\
\hline $\begin{array}{l}\text { Allers, M.A. and } \\
\text { de Greef J.A. } \\
(2018)\end{array}$ & empirical & country & quantitative & $\begin{array}{l}\text { regression, panel data, } \\
\text { secondary data, 2005- } \\
2013\end{array}$ \\
\hline $\begin{array}{l}\text { Allers, M.A. and } \\
\text { van Ommeren, B. } \\
\text { (2016) }\end{array}$ & empirical & country & quantitative & $\begin{array}{l}\text { regression, micro-level } \\
\text { dataset, 1997-2013 }\end{array}$ \\
\hline $\begin{array}{l}\text { Bel, G. and } \\
\text { Fageda, X. (2008) }\end{array}$ & empirical & country & quantitative & $\begin{array}{l}\text { regression: logit } \\
\text { technique, } \\
\text { primary/secondary data, } \\
2002,2003\end{array}$ \\
\hline $\begin{array}{l}\text { Bel, G. and } \\
\text { Fageda, X. (2009) }\end{array}$ & empirical & country & qualitative & $\begin{array}{l}\text { meta-regression: probit } \\
\text { model, secondary data, } \\
\text { 1979-2004 }\end{array}$ \\
\hline $\begin{array}{l}\text { Bel, G. and } \\
\text { Gradus, R. (2018) }\end{array}$ & non-empirical & cross-country & qualitative & literature review \\
\hline $\begin{array}{l}\text { Bel, G. and Mur, } \\
\text { M. (2009) }\end{array}$ & empirical & country & quantitative & $\begin{array}{l}\text { regression, } \\
\text { primary/secondary data, } \\
2003\end{array}$ \\
\hline $\begin{array}{l}\text { Bel, G. and } \\
\text { Warner, M.E. } \\
(2015)\end{array}$ & non-empirical & cross-country & qualitative & literature review \\
\hline
\end{tabular}




\begin{tabular}{|c|c|c|c|c|}
\hline Study & $\begin{array}{c}\text { Empirical/ } \\
\text { non-empirical } \\
\text { study }\end{array}$ & $\begin{array}{c}\text { Country/ } \\
\text { cross-country } \\
\text { study }\end{array}$ & $\begin{array}{c}\text { Qualitative/ } \\
\text { quantitative } \\
\text { study }\end{array}$ & $\begin{array}{c}\text { Research } \\
\text { method/model, data, } \\
\text { time frame }\end{array}$ \\
\hline $\begin{array}{l}\text { Bel, G. and } \\
\text { Warner, M.E. } \\
\text { (2016) }\end{array}$ & empirical & cross-country & qualitative & $\begin{array}{l}\text { meta-regression: probit } \\
\text { model, secondary data }\end{array}$ \\
\hline $\begin{array}{l}\text { Bel, G. et al., } \\
\text { (2010) }\end{array}$ & empirical & cross-country & quantitative & $\begin{array}{l}\text { explanatory/comparative } \\
\text { analysis, secondary data, } \\
2003,2006\end{array}$ \\
\hline $\begin{array}{l}\text { Bel, G. et al., } \\
\text { (2012) }\end{array}$ & empirical & country & quantitative & $\begin{array}{l}\text { regression, } \\
\text { primary/secondary data, } \\
2008\end{array}$ \\
\hline $\begin{array}{l}\text { Bel, G. et al., } \\
\text { (2013) }\end{array}$ & empirical & country & quantitative & $\begin{array}{l}\text { regression: binary probit } \\
\text { model, primary data, } \\
\text { 2003, } 2008\end{array}$ \\
\hline $\begin{array}{l}\text { Bel, G. et al., } \\
\text { (2007) }\end{array}$ & non-empirical & cross-country & qualitative & $\begin{array}{l}\text { descriptive/comparative } \\
\text { analysis }\end{array}$ \\
\hline $\begin{array}{l}\text { Bergman, P.A. et } \\
\text { al., (2016) }\end{array}$ & empirical & country & quantitative & $\begin{array}{l}\text { regression, panel data, } \\
\text { primary data, 1990- } \\
2009\end{array}$ \\
\hline $\begin{array}{l}\text { Blaesche, F. and } \\
\text { Haug, P. (2018) }\end{array}$ & empirical & country & quantitative & $\begin{array}{l}\text { unconditional FDH- } \\
\text { metafrontier, secondary } \\
\text { data, } 2006\end{array}$ \\
\hline $\begin{array}{l}\text { Carrozza, C. } \\
(2010)\end{array}$ & non-empirical & country & qualitative & $\begin{array}{l}\text { case study comparison, } \\
\text { primary/secondary data }\end{array}$ \\
\hline $\begin{array}{l}\text { Citroni, G. et al., } \\
\text { (2013) }\end{array}$ & empirical & country & $\begin{array}{l}\text { quantitative, } \\
\text { qualitative }\end{array}$ & $\begin{array}{l}\text { case study, secondary } \\
\text { data, } 2008\end{array}$ \\
\hline Czaplak, J. (2016) & empirical & country & quantitative & $\begin{array}{l}\text { multy-faceted analysis, } \\
\text { primary/secondary data, } \\
2007-2013\end{array}$ \\
\hline $\begin{array}{l}\text { Dijkgraaf, E. and } \\
\text { Gradus, R. (2013) }\end{array}$ & empirical & country & quantitative & $\begin{array}{l}\text { regression: cost function } \\
\text { estimation, panel data, } \\
\text { secondary data, 1998- } \\
2010\end{array}$ \\
\hline $\begin{array}{l}\text { Garrone, P. and } \\
\text { Marzano, R. } \\
(2015)\end{array}$ & empirical & country & $\begin{array}{l}\text { quantitative, } \\
\text { qualitative }\end{array}$ & $\begin{array}{l}\text { mixed duration models, } \\
\text { primary data, 2001- } \\
2012\end{array}$ \\
\hline $\begin{array}{l}\text { Girth, A.M. et al. } \\
\text { (2012) }\end{array}$ & empirical & country & $\begin{array}{l}\text { quantitative, } \\
\text { qualitative }\end{array}$ & $\begin{array}{l}\text { regression, multi- } \\
\text { method approach, } \\
\text { primary data, 2007, } \\
2008-2010,\end{array}$ \\
\hline $\begin{array}{l}\text { González-Gómez, } \\
\text { F. et al., (2011) }\end{array}$ & empirical & country & quantitative & $\begin{array}{l}\text { regression: binominal } \\
\text { discrete choice model, } \\
\text { secondary data, 1985- } \\
2006\end{array}$ \\
\hline $\begin{array}{l}\text { Grešová, L. and } \\
\text { Fuka, J. (2018) }\end{array}$ & empirical & country & $\begin{array}{l}\text { quantitative, } \\
\text { qualitative }\end{array}$ & $\begin{array}{l}\text { data envelopment } \\
\text { analysis, primary data, } \\
\text { 2010-2014 }\end{array}$ \\
\hline
\end{tabular}




\begin{tabular}{|c|c|c|c|c|}
\hline Study & $\begin{array}{c}\text { Empirical/ } \\
\text { non-empirical } \\
\text { study }\end{array}$ & $\begin{array}{c}\text { Country/ } \\
\text { cross-country } \\
\text { study }\end{array}$ & $\begin{array}{c}\text { Qualitative/ } \\
\text { quantitative } \\
\text { study }\end{array}$ & $\begin{array}{c}\text { Research } \\
\text { method/model, data, } \\
\text { time frame }\end{array}$ \\
\hline $\begin{array}{l}\text { Hefetz, A. and } \\
\text { Warner, M.E. } \\
(2011)\end{array}$ & empirical & country & qualitative & $\begin{array}{l}\text { regression: } \\
\text { multinominal logit } \\
\text { models, } \\
\text { primary/secondary data, } \\
2007\end{array}$ \\
\hline $\begin{array}{l}\text { Hefetz, A. et al., } \\
(2012)\end{array}$ & empirical & country & $\begin{array}{l}\text { qualitative, } \\
\text { quantitative }\end{array}$ & $\begin{array}{l}\text { regression: probit } \\
\text { models, secondary data, } \\
1992-2007\end{array}$ \\
\hline $\begin{array}{l}\text { Hulst, R. et al. } \\
\text { (2009) }\end{array}$ & non-empirical & cross-country & qualitative & $\begin{array}{l}\text { comparative analysis, } \\
\text { secondary data }\end{array}$ \\
\hline $\begin{array}{l}\text { Hultquist, A. et } \\
\text { al., (2017) }\end{array}$ & empirical & country & $\begin{array}{l}\text { qualitative, } \\
\text { quantitative }\end{array}$ & $\begin{array}{l}\text { regression: } \\
\text { multinominal logit } \\
\text { model, primary data, } \\
2014\end{array}$ \\
\hline Kim, Y. (2018) & empirical & country & qualitative & $\begin{array}{l}\text { regression: probit } \\
\text { model, primary data, } \\
2012\end{array}$ \\
\hline $\begin{array}{l}\text { Kim, Y. and } \\
\text { Warner, M.E. } \\
(2016)\end{array}$ & empirical & country & qualitative & $\begin{array}{l}\text { regression: probit } \\
\text { model, primary data, } \\
2012\end{array}$ \\
\hline $\begin{array}{l}\text { Klimovský, D. et } \\
\text { al. (2014) }\end{array}$ & empirical & cross-country & qualitative & $\begin{array}{l}\text { descriptive/comparative } \\
\text { analysis, primary data, } \\
2013\end{array}$ \\
\hline $\begin{array}{l}\text { Krueger, S. et al., } \\
\text { (2011) }\end{array}$ & empirical & country & $\begin{array}{l}\text { quantitative, } \\
\text { qualitative }\end{array}$ & $\begin{array}{l}\text { regression: } \\
\text { multinominal logistic } \\
\text { model, secondary data, } \\
1997\end{array}$ \\
\hline $\begin{array}{l}\text { Lamothe et al. } \\
\text { (2008) }\end{array}$ & empirical & country & $\begin{array}{l}\text { quantitative, } \\
\text { qualitative }\end{array}$ & $\begin{array}{l}\text { regression: } \\
\text { multinominal logit } \\
\text { model, secondary data, } \\
1997,2002\end{array}$ \\
\hline $\begin{array}{l}\text { Levin, J. and } \\
\text { Tadelis, S. (2010) }\end{array}$ & empirical & country & $\begin{array}{l}\text { quantitative, } \\
\text { qualitative }\end{array}$ & $\begin{array}{l}\text { multivariate regression: } \\
\text { multinominal logit } \\
\text { model, primary data, } \\
1997,2002\end{array}$ \\
\hline $\begin{array}{l}\text { Marvel, M.K. and } \\
\text { Marvel, H.P. } \\
\text { (2007) }\end{array}$ & empirical & country & qualitative & $\begin{array}{l}\text { regression, primary data, } \\
2002\end{array}$ \\
\hline $\begin{array}{l}\text { Mohr, R. et al., } \\
\text { (2010) }\end{array}$ & empirical & country & $\begin{array}{l}\text { quantitative, } \\
\text { qualitative }\end{array}$ & $\begin{array}{l}\text { regression: logit, probit } \\
\text { model, primary data, } \\
\text { 1995, 1997, } 2004\end{array}$ \\
\hline $\begin{array}{l}\text { Monteduro, F. } \\
\text { (2014) }\end{array}$ & empirical & country & quantitative & $\begin{array}{l}\text { regression: OLS and } \\
\text { Student's t test, } \\
\text { secondary data, 2004- } \\
2006\end{array}$ \\
\hline
\end{tabular}




\begin{tabular}{|c|c|c|c|c|}
\hline Study & $\begin{array}{c}\text { Empirical/ } \\
\text { non-empirical } \\
\text { study }\end{array}$ & $\begin{array}{c}\text { Country/ } \\
\text { cross-country } \\
\text { study }\end{array}$ & $\begin{array}{l}\text { Qualitative/ } \\
\text { quantitative } \\
\text { study }\end{array}$ & $\begin{array}{c}\text { Research } \\
\text { method/model, data, } \\
\text { time frame }\end{array}$ \\
\hline $\begin{array}{l}\text { Nemec, J. et al., } \\
(2015)\end{array}$ & empirical & cross-country & quantitative & $\begin{array}{l}\text { 1)cost-minimization } \\
\text { method, primary data, } \\
\text { 2000-2011 } \\
\text { 2)basic statistical } \\
\text { analysis, secondary data, } \\
\text { 2008-2012 } \\
\text { 3) basic statistical } \\
\text { analysis, secondary data, } \\
\text { 2008-2012 }\end{array}$ \\
\hline $\begin{array}{l}\text { Petersen et al. } \\
\text { (2015) }\end{array}$ & empirical & country & quantitative & $\begin{array}{l}\text { regression: OLS } \\
\text { regressions with cluster- } \\
\text { corrected standard } \\
\text { errors, panel data, } \\
\text { secondary data, 2007- } \\
2012\end{array}$ \\
\hline $\begin{array}{l}\text { Rayle, L. and } \\
\text { Zegras, C. (2013) }\end{array}$ & empirical & country & qualitative & $\begin{array}{l}\text { case study, primary and } \\
\text { secondary data, 1990- } \\
2009\end{array}$ \\
\hline $\begin{array}{l}\text { Rodrigues, M. et } \\
\text { al., (2012) }\end{array}$ & empirical & country & $\begin{array}{l}\text { quantitative, } \\
\text { qualitative }\end{array}$ & $\begin{array}{l}\text { regression: } \\
\text { multinominal logit } \\
\text { model, } \\
\text { primary/secondary data, } \\
2008\end{array}$ \\
\hline $\begin{array}{l}\text { Schoute, M. et al. } \\
\text { (2018) }\end{array}$ & empirical & country & $\begin{array}{l}\text { quantitative, } \\
\text { qualitative }\end{array}$ & $\begin{array}{l}\text { regression: } \\
\text { multinominal logit } \\
\text { model, } \\
\text { primary/secondary data, } \\
2010\end{array}$ \\
\hline $\begin{array}{l}\text { Soukopová, J. and } \\
\text { Vaceková, G. } \\
\text { (2018) }\end{array}$ & empirical & country & quantitative & $\begin{array}{l}\text { multiple regression: } \\
\text { OLS model, } \\
\text { primary/secondary data, } \\
2012-2014\end{array}$ \\
\hline $\begin{array}{l}\text { Sundell, A. and } \\
\text { Lapuente, V. } \\
\text { (2012) }\end{array}$ & empirical & country & qualitative & $\begin{array}{l}\text { regression: OLS and } \\
\text { FEVD model, primary } \\
\text { data, } 2008\end{array}$ \\
\hline $\begin{array}{l}\text { Tavares, A.F. and } \\
\text { Camöes, P.J. } \\
\text { (2007) }\end{array}$ & empirical & country & quantitative & $\begin{array}{l}\text { regression: multivariate } \\
\text { probit model, secondary } \\
\text { data, } 1999-2002\end{array}$ \\
\hline $\begin{array}{l}\text { Warner, M.E. } \\
(2008)\end{array}$ & non-empirical & cross-country & qualitative & $\begin{array}{l}\text { descriptive analysis, } \\
\text { secondary data }\end{array}$ \\
\hline $\begin{array}{l}\text { Warner, M.E. } \\
\text { (2011) }\end{array}$ & empirical & country & qualitative & $\begin{array}{l}\text { correlation analysis, } \\
\text { primary/secondary data, } \\
2007\end{array}$ \\
\hline $\begin{array}{l}\text { Warner, M.E. and } \\
\text { Bel, G. (2008) }\end{array}$ & empirical & cross-country & quantitative & $\begin{array}{l}\text { comparative/explanatory } \\
\text { analysis, secondary data }\end{array}$ \\
\hline $\begin{array}{l}\text { Warner, M.E. and } \\
\text { Hefetz, A. (2012) }\end{array}$ & empirical & country & $\begin{array}{l}\text { quantitative, } \\
\text { qualitative }\end{array}$ & $\begin{array}{l}\text { regression: probit } \\
\text { models, } \\
\text { primary/secondary data, } \\
2002-2007\end{array}$ \\
\hline
\end{tabular}




\begin{tabular}{|l|l|l|l|l|}
\hline \multicolumn{1}{|c|}{ Study } & $\begin{array}{c}\text { Empirical/ } \\
\text { non-empirical } \\
\text { study }\end{array}$ & $\begin{array}{c}\text { Country/ } \\
\text { cross-country } \\
\text { study }\end{array}$ & $\begin{array}{c}\text { Qualitative/ } \\
\text { quantitative } \\
\text { study }\end{array}$ & $\begin{array}{c}\text { Research } \\
\text { method/model, data, } \\
\text { time frame }\end{array}$ \\
\hline $\begin{array}{l}\text { Wassenaar, M. et } \\
\text { al. (2013) }\end{array}$ & empirical & country & $\begin{array}{l}\text { quantitative, } \\
\text { qualitative }\end{array}$ & $\begin{array}{l}\text { regression: binary logit } \\
\text { model, primary data, } \\
2009\end{array}$ \\
\hline $\begin{array}{l}\text { Wollmann, H. } \\
(2011)\end{array}$ & non-empirical & cross-country & qualitative & $\begin{array}{l}\text { comparative analysis, } \\
\text { secondary data }\end{array}$ \\
\hline $\begin{array}{l}\text { Zafra- Gómez et } \\
\text { al., (2013) }\end{array}$ & empirical & country & quantitative & $\begin{array}{l}\text { regression: dual cost } \\
\text { function, panel data, } \\
\text { secondary data, 2002- } \\
\text { 2008 }\end{array}$ \\
\hline
\end{tabular}

Table 3: Costs as a decision-making factor for public service delivery mechanism

\begin{tabular}{|c|c|c|c|c|}
\hline $\begin{array}{c}\text { Delivery } \\
\text { mechanism }\end{array}$ & $\begin{array}{c}\text { No of } \\
\text { studies }\end{array}$ & Author(s) & $\begin{array}{c}\text { Main } \\
\text { research } \\
\text { topic }\end{array}$ & Main findings \\
\hline Privatization & 4 & $\begin{array}{l}\text { Bel and Fageda, 2008; } \\
\text { Hultquist et al., 2017; } \\
\text { Nemec et al., 2015; } \\
\text { Zafra-Gómez et al., } \\
2013\end{array}$ & cost reduction & $\begin{array}{l}\text { less common for } \\
\text { services with higher } \\
\text { transaction costs and } \\
\text { for small local } \\
\text { governments }\end{array}$ \\
\hline IMC & 3 & $\begin{array}{l}\text { Bel and Warner, 2015; } \\
\text { Bel et al., 2012; } \\
\text { Soukopová and } \\
\text { Vaceková, 2018 }\end{array}$ & $\begin{array}{l}\text { cost } \\
\text { reduction, } \\
\text { size of local } \\
\text { governments }\end{array}$ & $\begin{array}{l}\text { a pragmatic choice } \\
\text { for local } \\
\text { governments with } \\
\text { suboptimal size }\end{array}$ \\
\hline $\begin{array}{l}\text { Privatization vs } \\
\text { IMC }\end{array}$ & 6 & $\begin{array}{l}\text { Bel and Mur, 2009; } \\
\text { Bel et al., 2010; } \\
\text { Bel et al., 2013; } \\
\text { Hefetz and Warner, } \\
2011 \text {; } \\
\text { Mohr et al., 2010; } \\
\text { Dijkgraaf and Gradus, } \\
2013\end{array}$ & $\begin{array}{l}\text { cost } \\
\text { reduction, } \\
\text { size of local } \\
\text { governments }\end{array}$ & $\begin{array}{l}\text { small local } \\
\text { governments prefer } \\
\text { IMC; large local } \\
\text { governments prefer } \\
\text { privatization; } \\
\text { IMC is an important } \\
\text { alternative }\end{array}$ \\
\hline
\end{tabular}

Table 4: Economies of scale as a decision-making factor for the public service delivery mechanism

\begin{tabular}{|l|l|l|l|l|}
\hline $\begin{array}{c}\text { Delivery } \\
\text { mechanism }\end{array}$ & $\begin{array}{c}\text { No of } \\
\text { studies }\end{array}$ & Author(s) & \multicolumn{1}{|c|}{$\begin{array}{c}\text { Main research } \\
\text { topic }\end{array}$} & \multicolumn{1}{|c|}{ Main findings } \\
\hline Privatization & 1 & $\begin{array}{l}\text { Levin and } \\
\text { Tadelis, 2010 }\end{array}$ & $\begin{array}{l}\text { economies of } \\
\text { scale, size of local } \\
\text { government }\end{array}$ & $\begin{array}{l}\text { large local governments } \\
\text { most often privatize }\end{array}$ \\
\hline IMC & 1 & Warner, 2011 & $\begin{array}{l}\text { economies of } \\
\text { scale, size of local } \\
\text { government }\end{array}$ & $\begin{array}{l}\text { IMC is an important } \\
\text { alternative when market } \\
\text { competition is limited }\end{array}$ \\
\hline
\end{tabular}


Table 5: Efficiency as a decision-making factor for the public service delivery mechanism

\begin{tabular}{|c|c|c|c|c|}
\hline $\begin{array}{c}\text { Delivery } \\
\text { mechanism }\end{array}$ & $\begin{array}{c}\text { No of } \\
\text { studies }\end{array}$ & Author(s) & $\begin{array}{c}\text { Main research } \\
\text { topic }\end{array}$ & Main findings \\
\hline Privatization & 2 & $\begin{array}{l}\text { Garrone and } \\
\text { Marzano, 2015; } \\
\text { Warner, 2008 }\end{array}$ & efficiency gains & $\begin{array}{l}\text { more likely in cases } \\
\text { where scale and } \\
\text { managerial efficiency } \\
\text { have already been } \\
\text { enhanced }\end{array}$ \\
\hline IMC & 4 & $\begin{array}{l}\text { Allers and de } \\
\text { Greef, 2018; } \\
\text { Allers and van } \\
\text { Ommeren, 2016; } \\
\text { Blaesche and } \\
\text { Haug, 2018; } \\
\text { Grešová and } \\
\text { Fuka, } 2018\end{array}$ & efficiency gains & $\begin{array}{l}\text { no evidence that IMC } \\
\text { improves efficiency }\end{array}$ \\
\hline $\begin{array}{l}\text { Privatization } \\
\text { vs IMC }\end{array}$ & 3 & $\begin{array}{l}\text { Hefetz et al., } \\
2012 \text {; } \\
\text { Czaplak, 2016; } \\
\text { Monteduro, } \\
2014\end{array}$ & efficiency gains & $\begin{array}{l}\text { public-private } \\
\text { provision shows better } \\
\text { economic performance }\end{array}$ \\
\hline
\end{tabular}

Table 6: Economic-political decision-making factors for the public service delivery mechanism

\begin{tabular}{|c|c|c|c|c|}
\hline $\begin{array}{c}\text { Delivery } \\
\text { mechanism }\end{array}$ & $\begin{array}{c}\text { No of } \\
\text { studies }\end{array}$ & Author(s) & $\begin{array}{c}\text { Main research } \\
\text { topic }\end{array}$ & Main findings \\
\hline Privatization & 5 & $\begin{array}{l}\text { Bel and Fageda, } \\
\text { 2009; } \\
\text { Carrozza, 2010; } \\
\text { Rodrigues et al., } \\
2012 ; \\
\text { Sundell and } \\
\text { Lapuente, 2012; } \\
\text { Warner and } \\
\text { Hefetz, } 2012\end{array}$ & $\begin{array}{l}\text { influence of } \\
\text { economic-political } \\
\text { environment on } \\
\text { private provision }\end{array}$ & $\begin{array}{l}\text { service characteristics, } \\
\text { local political } \\
\text { environment play a } \\
\text { key role }\end{array}$ \\
\hline In-house & 1 & $\begin{array}{l}\text { Tavares and } \\
\text { Camöes, } 2007\end{array}$ & $\begin{array}{l}\text { influence on private } \\
\text { or in-house } \\
\text { provision }\end{array}$ & $\begin{array}{l}\text { political and socio- } \\
\text { economic context have } \\
\text { important influence }\end{array}$ \\
\hline
\end{tabular}


Table 7: Economic-institutional-social decision-making factors for the public service delivery mechanism

\begin{tabular}{|l|l|l|l|l|}
\hline $\begin{array}{c}\text { Delivery } \\
\text { mechanism }\end{array}$ & $\begin{array}{c}\text { No of } \\
\text { studies }\end{array}$ & \multicolumn{1}{c|}{ Author(s) } & \multicolumn{1}{c|}{$\begin{array}{c}\text { Main research } \\
\text { topic }\end{array}$} & \multicolumn{1}{c|}{ Main findings } \\
\hline Privatization & 4 & $\begin{array}{l}\text { Bel et al., 2007; } \\
\text { González-Gómez et } \\
\text { al., 2011; } \\
\text { Petersen et al., 2015; } \\
\text { Wassenar et al., 2013 }\end{array}$ & $\begin{array}{l}\text { specifics of } \\
\text { institutional- and } \\
\text { social-economic } \\
\text { factors }\end{array}$ & $\begin{array}{l}\text { size of local government, } \\
\text { financial burden, } \\
\text { neighboring effect, } \\
\text { complex operating } \\
\text { environment have higher } \\
\text { relevance, ideology has } \\
\text { less importance }\end{array}$ \\
\hline IMC & 4 & $\begin{array}{l}\text { Bel and Warner, } \\
2016 ; \\
\text { Hulst et al., 2009; } \\
\text { Klimovsky et al., } \\
2014 ; \\
\text { Rayle and Zegras, } \\
2013\end{array}$ & $\begin{array}{l}\text { impact of } \\
\text { institutional- and } \\
\text { social-economic } \\
\text { factors }\end{array}$ & $\begin{array}{l}\text { fiscal constraints, spatial } \\
\text { and organizational } \\
\text { factors, flexibility in } \\
\text { institutional system, } \\
\text { existing } \\
\text { interorganizational } \\
\text { networks are significant } \\
\text { drivers of IMC }\end{array}$ \\
\hline & & & & \\
\end{tabular}

Table 8: Other economic decision-making factors for the public service delivery mechanism

\begin{tabular}{|c|c|c|c|c|}
\hline $\begin{array}{c}\text { Delivery } \\
\text { mechanism }\end{array}$ & $\begin{array}{c}\text { No of } \\
\text { studies }\end{array}$ & Author(s) & $\begin{array}{l}\text { Main research } \\
\text { topic }\end{array}$ & Main findings \\
\hline Privatization & 5 & $\begin{array}{l}\text { Bergman et al., } \\
2016 ; \\
\text { Krueger et al., 2011; } \\
\text { Lamothe et al., } \\
2008 ; \\
\text { Marvel and Marvel, } \\
\text { 2007; } \\
\text { Schoute et al., } 2018\end{array}$ & $\begin{array}{l}\text { influence of other } \\
\text { economic factors }\end{array}$ & $\begin{array}{l}\text { asset specificity, inertial } \\
\text { effects, competitiveness } \\
\text { of the contract } \\
\text { environment, monitoring } \\
\text { the service provision, } \\
\text { emphasis regarding } \\
\text { outcome performance } \\
\text { influence privatization }\end{array}$ \\
\hline IMC & 2 & $\begin{array}{l}\text { Citroni et al., 2013; } \\
\text { Wollmann, } 2011\end{array}$ & $\begin{array}{l}\text { influence of } \\
\text { corporatization } \\
\text { and other } \\
\text { economic factors }\end{array}$ & $\begin{array}{l}\text { corporatization increases } \\
\text { IMC }\end{array}$ \\
\hline $\begin{array}{l}\text { Privatization } \\
\text { vs. IMC }\end{array}$ & 5 & $\begin{array}{l}\text { Bel and Gradus, } \\
\text { 2018; } \\
\text { Girth et al., 2012; } \\
\text { Kim and Warner, } \\
\text { 2016; } \\
\text { Kim, 2018; } \\
\text { Warner and Bel, } \\
2008\end{array}$ & $\begin{array}{l}\text { factors driving } \\
\text { delivery choices } \\
\text { and effects of } \\
\text { each delivery } \\
\text { choice on service } \\
\text { provision }\end{array}$ & $\begin{array}{l}\text { fiscal stress and } \\
\text { community needs } \\
\text { influence the use of } \\
\text { alternative delivery } \\
\text { methods }\end{array}$ \\
\hline
\end{tabular}

